\title{
Gender and Age Effect on Acceptance of Internet Banking: Cultural Comparison between United States and Malaysia
}

\author{
Yee Yen Yuen ${ }^{1}$ \\ ${ }^{1}$ Faculty of Business, Multimedia University, Malaysia \\ Correspondence: Yee Yen Yuen, Faculty of Business, Multimedia University, Jalan Ayer Keroh Lama, 75450 \\ Melaka, Malaysia. E-mail: yyyuen@mmu.edu.my
}

Received: May 30, 2013

Accepted: July 5, 2013

Online Published: August 20, 2013

doi:10.5539/ijbm.v8n18p1

URL: http://dx.doi.org/10.5539/ijbm.v8n18p1

\begin{abstract}
Weak marketing strategies of emphasizing the same Internet banking features in different countries have failed to accurately suit the local demands. As one percent increase in the retention of Internet banking acceptance will typically bring 18 percent reduction in operating cost (Bhattacherjee, 2001), indifference towards consumers' adoption of Internet banking services may result in a big loss to the financial institutions. Therefore, this study is conducted to help banks mitigate the key cause of profit reduction in Internet banking industry which is an insufficient understanding of customer behaviour and preference by recommending effective strategies to help banks retain existing Internet banking customers. A questionnaire was developed based on the theoretical framework, tested in a pilot study, and finally distributed to a sample of 1,200 Internet banking users from major cities in the United States and Malaysia. Malaysian females have significantly higher behavioural intention to use Internet banking services compared to their counterparts in the United States. Young adults in the United States are more likely to be influenced by their social environment when using Internet banking services while middle-aged adults from Malaysia rank significantly higher on behavioural intention to use Internet banking services, performance expectancy, effort expectancy, facilitating conditions and attitude towards using Internet banking. The study is also the among the very few available research that attempts to discuss cultural differences of Internet banking acceptance of the United States and Malaysia by applying a combination of Hofstede (2001) and Trompenaars and Hampden-Turner (1998)'s cultural dimensions.
\end{abstract}

Keywords: internet banking, cultural impact, gender, age, United States, Malaysia

\section{Introduction}

As Internet access exceeded 2.4 billion people globally in the second quarter of 2012 (Internet World Stats, 2013), a growing number of banks worldwide have increased their business investments in Internet banking driven by the expectation that the Internet technology would provide better opportunities to establish a distinctive strategic position compared to other traditional forms of banking services (Evans \& Wurster, 1997).Internet banking is particularly well-practiced in the developed countries such as Korea, Spain, and Austria, where more than 75 percent of all banks offer transactional services via the Internet (Maenpaa, 2006). The development of the Internet banking has breached the geographical barriers, creating new products, services and market opportunities (Dauda \& Santhaparraj, 2008; Khalil \& Pearson, 2007).

Contrary to the expectations of most bankers worldwide, the profits of banks, in overall, have not increased following the offering of Internet banking services (Capgemini, UniCredit, \& European Financial Management and Marketing Association, 2009; Sullivan, 2000). According to the World Retail Banking Report 2013, nearly $10 \%$ of the bank customers were unlikely to stay with the same banks in the next six months, while more than $40 \%$ were unsure if they would do so (Capgemini et al., 2013). Community banks and chartered banks with less than two years' experience in offering Internet banking services tend to suffer from the largest reduction in profits due to extraordinarily high expenses (Sciglimpaglia \& Ely, 2002).

The main reason that causes the reduction in the loyalty of bank customers is insufficient understanding of customers' behaviours and preferences (Hussain, Chang, Hussain, \& Dillon, 2009). Online services can be a failure if the company cannot understand customers' expectations well (Hussain et al., 2009).

Weak marketing strategies of emphasizing the same Internet banking features in different countries have failed 
to accurately suit the local demands. As one percent increase in the retention of Internet banking acceptance will typically bring 18 percent reduction in operating cost (Bhattacherjee, 2001), indifference towards consumers' adoption of Internet banking services may result in a big loss to the financial institutions. Therefore, this study is conducted to help banks mitigate the key cause of profit reduction in Internet banking industry which is an insufficient understanding of customer behaviour and preference by recommending effective strategies to help banks retain existing Internet banking customers.

Understanding Internet banking acceptance from the context of cultural differences is not addressed in previous studies. Most studies focused narrowly on the positive aspects of Internet banking services. For example, AbuShanab and Pearson (2007), Eriksson et al. (2005) and Yazan (2008) focused on the effects of trust, relative advantage and attitude toward using Internet banking services. Other studies mainly concentrated on the influence of perceived security on Internet banking acceptance (Dauda \& Santhaparraj, 2008; Khalil \& Pearson, 2007). Literature such as Gerrard and Cunningham (2003) and Saythe (1999) did not test the validity and reliability of constructs. Sathye (1999) stated that 70 percent of customers were concerned about the security of using Internet banking services and Gerrard and Cunningham (2003) identified economic benefits of Internet banking acceptance without providing further statistical analysis to confirm the reliability and validity of the collected data.

On top of that, most literature focuses on examining difference in gender adoption of Internet banking services without taking into consideration of the cultural impact. For example, Lichtenstein and Williamson (2006) revealed that female users had busy lives with children. Morahan-Martin (2000) mentioned that women were less interested in using the Internet. Capgemini et al. (2004) disclosed that men comprised of the majority of online users of financial services (76 percent) in European countries. Vainio (2006) discovered that females did not view Internet banking services as useful as males. All these studies neglect the cultural effect in the discussion of findings.

With regards to age groups, there is also limited literature that examines cultural impact on Internet banking acceptance in the United States and Malaysia. Karjaluotoet al. (2009) showed that young people are generally more inclined to adopt Internet banking. Alagheband (2006) asserted that young individuals were more likely to adopt Internet banking. All these studies discussed Internet banking acceptance of young and older generations in general without taking into the context of cultural difference.

As one of the very few studies that examines the examines cultural differences of Internet banking acceptance from the perspective of different genders and age groups the United States and Malaysia, this study contributes to the current knowledge of Internet banking acceptance. The study is also the among the very few available research that attempts to discuss cultural differences of Internet banking acceptance of the United States and Malaysia by applying a combination of Hofstede (2001) and Trompenaars and Hampden-Turner (1998)'s cultural dimensions.

\section{Literature Reviews}

\subsection{Behavioural Intention to Use Internet Banking}

Behavioural intention to use Internet banking is post-acceptance behaviour which involves repeat purchasing of product/services in the coming future (Ali \& Khalil, 2013; Homburg \& Giering, 2001). Success in the Internet-based market primarily depends on behavioural intention to continue using Internet banking services rather than first-time use (Ali \& Khalil, 2013; Hsu et al., 2006; Roca et al., 2006). The following hypotheses are tested in this study:

H1: There is a difference in behavioural intention to use Internet banking services of different genders in the United States and Malaysia.

$\mathrm{H} 2$ : There is a difference in behavioural intention to use Internet banking services of different age groups in the United States and Malaysia.

User acceptance of Internet banking services could be hampered or encouraged by the following independent variables.

\subsection{Performance Expectancy}

The first independent variable, performance expectancy can be defined as user perception that a technology can increase productivity (Calisir \& Gumussoy, 2008; Gounaris \& Koritos, 2008; Raman \& Don, 2013). Accessibility is an important aspect associated with the performance expectancy of Internet banking (Polatoglu \& Ekin, 2001; Raman\& Don, 2013; Rotchanakitumnuai \& Speece, 2003). As discovered by Polatoglu and Ekin 
(2001), the Internet enables users to visit an online banking website at any time and from any location more easily and efficiently. In comparison with traditional banking, Internet banking is able to reach far more people and keep away people from waiting in lines. It offers greater convenience and time saving benefits of consumers from different genders and age groups.

Therefore, the following hypotheses are tested in this study.

H3: Performance expectancy affects behavioural intention to use Internet banking services of different genders in the United States and Malaysia.

H4: Performance expectancy affects behavioural intention to use Internet banking services of different age groups in the United States and Malaysia.

\subsection{Effort Expectancy}

Another important indicator, effort expectancy, refers to user perception that it requires minimum effort to use a technology. Chen and Barnes (2007) discovered that one of the crucial technological aspects of the online interface which significantly affected customer acceptance was effort expectancy. Calisir and Gumussoy (2008) affirmed effort expectancy as a key driver of growth in Internet banking acceptance. The ability of an Internet bank to ensure fast download time and avoid the downtimes would possibly influenced Internet banking acceptance of consumers from different genders and age groups (Calisir \& Gumussoy, 2008; Floh \& Treiblmaier, 2006; Raman \& Don, 2013). Therefore, the following hypotheses are tested in this study.

H5: Effort expectancy affects behavioural intention to use Internet banking services of different genders in the United States and Malaysia.

H6: Effort expectancy affects behavioural intention to use Internet banking services of different age groups in the United States and Malaysia.

\subsection{Social Influence}

The third indicator, social influence measures the effect organizational and peer support on technology acceptance (Raman \& Don, 2013; Taylor \&Todd, 1995). With a high extent of interdependence among workers in carrying out a particular duty, social support from colleagues is particularly important for the attainment of specific goal such as increased productivity in an organization (Raman \& Don, 2013; Yang et al., 2009). Technology acceptance in an organization can improve a worker's relationship with other workers and result in better social exchange and coalition formation (Raman \& Don, 2013; Yang et al., 2009). Therefore, the following hypotheses are tested in this study.

H7: Social influence affects behavioural intention to use Internet banking services of different genders in the United States and Malaysia.

H8: Social influence affects behavioural intention to use Internet banking services of different age groups in the United States and Malaysia.

\subsection{Facilitating Conditions}

Facilitating conditions is the next indicator which has a direct influence on Internet banking acceptance. It refers to the availability of resources such as written documents and technological infrastructure in supporting the use of a new technology (Ajzen \& Driver, 1992; Raman \& Don, 2013). The development of Internet banking has allowed banks to offer Internet access to more people (Karjaluoto et al., 2009; Raman \& Don, 2013). In fact, Internet banking will only be more feasible to respond to customers' requests promptly if all hardware and software resources are easily and readily available (Karjaluoto et al., 2009; Raman \& Don, 2013).

H9: Facilitating conditions affect behavioural intention to use Internet banking services of different genders in the United States and Malaysia.

H10: Facilitating conditions affect behavioural intention to use Internet banking services of different age groups in the United States and Malaysia.

\subsection{Perceived Credibility}

Perceived credibility is an important predictor of behavioural intention to use Internet banking services. The lack of physical interactions between bank personnel and customers render Internet banking a unique environment in which perceived credibility is of supreme importance (Angie \& Chow, 2006; Kumar, 2013; Mukherjee \& Nath, 2003; Shumaila et al., 2009). An increase in the perceived credibility will subsequently improve users' Internet banking acceptance. Insufficient trust on financial institutions is a critical perceived credibility issues that lower Internet banking acceptance because it makes consumers scared to provide sensitive personal information on the 
Internet (Angie \& Chow, 2006; Kumar, 2013; Shumaila et al., 2009). Therefore, creating customer trust is an essential way to retain existing bank customers (Kumar, 2013; Mukherjee \& Nath, 2003). Therefore, the following hypotheses are tested in this study.

H11: Perceived credibility affects behavioural intention to use Internet banking services of different genders in the United States and Malaysia.

H12: Perceived credibility affects behavioural intention to use Internet banking services of different age groups in the United States and Malaysia.

\subsection{Attitude towards Using Internet Banking}

The last variable, attitude towards using Internet banking, refers to overall enjoyment and pleasure to use a technology (Davis, 1989; Kumar, 2013; Taylor \& Todd, 1995; Thompson et al., 1991; Zolait, Mattila, \&Ainin, 2009). An individual's delight or aversion in using a technology, influence his future technology acceptance (Dinev et al., 2009; Kumar, 2013; Venkatesh et al., 2003; Zolait et al., 2009).As discovered by Yang et al. (2009), users were not adopting the use of Internet banking services as rapidly as expected, even in developed country such as Australia due to the lack of interest in Internet banking services. Internet banking users had more positive attitudes whereas non-users have more negative attitude towards acceptance (Kumar, 2013; Rotchanakitumnuai \& Speece, 2003). Therefore, the following hypotheses are tested in this study.

H13: Attitude towards using Internet banking affects behavioural intention to use Internet banking services of different genders in the United States and Malaysia.

H14: Attitude towards using Internet banking affects behavioural intention to use Internet banking services of different age groups in the United States and Malaysia.

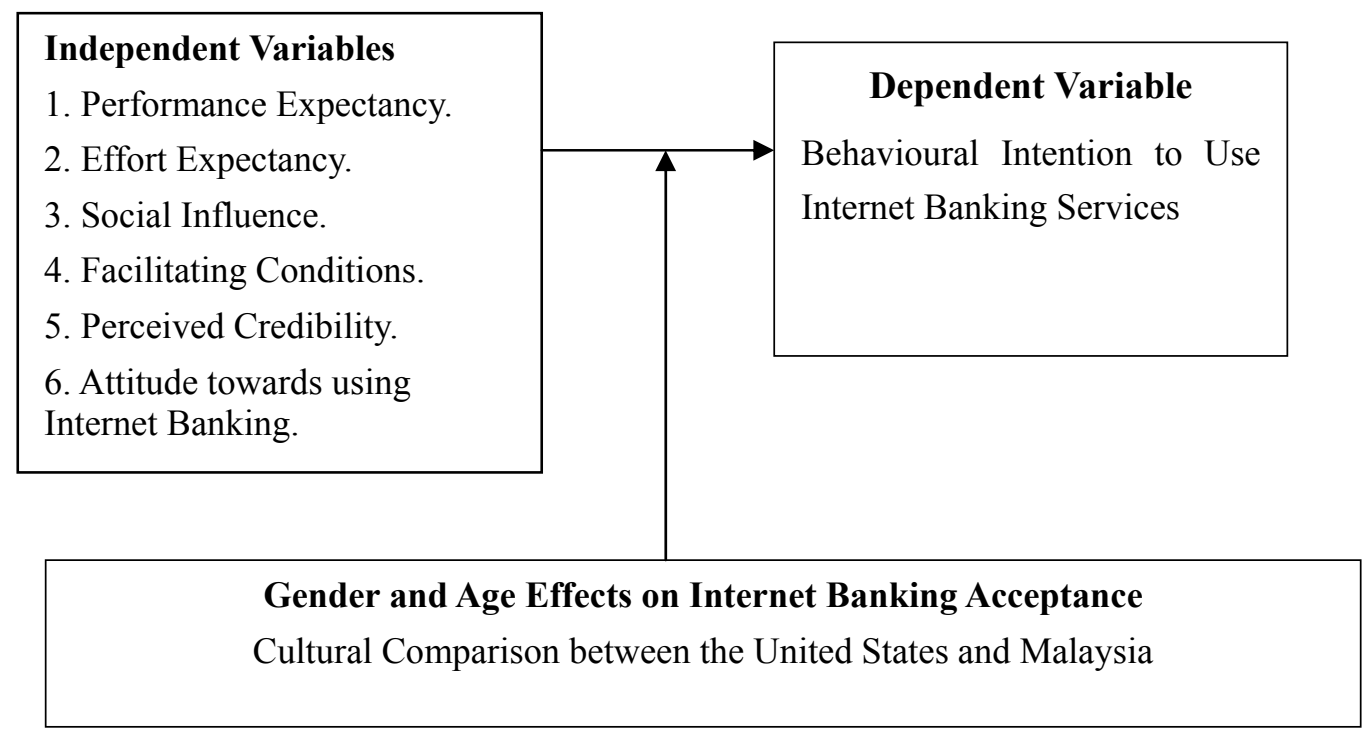

Figure 1. Research framework

\section{Research Method}

This study applied a formal standardized questionnaire in testing Internet banking acceptance of the respondents in the United States and Malaysia. A questionnaire was developed based on the theoretical framework, tested in a pilot study, and finally distributed to a sample of 1,200 Internet banking users from major cities in the United States and Malaysia. Internet banking users (who meet the 6 months' experience criteria) in the United States and Malaysia were contacted either through face-to-face meeting, postal mail or e-mail. Each respondent was requested to distribute the survey questionnaire to other Internet banking users such as friends, colleagues, and relatives. Snowball (non-random) sampling method (Henry, 1998; Schutt, 2008; Sekaran, 2000) was applied because there was no ways of obtaining the population frame. Lumpur were contacted either through face-to-face meeting, postal mail or e-mail. Each respondent was requested to distribute the survey questionnaire to other Internet banking users such as friends, colleagues, and relatives. A complete list of customers' contact 
from financial institutions could not be obtained because the Gramm-Leach-Bliley Act (1999) in the United States and the Banking and Financial Institution Act (1989) in Malaysia disallow banks to disclose such information.

Section A of the questionnaire comprises 18 demographic questions, such as gender, age, employment, visits to a physical bank branches, online purchasing experience and Internet banking experience. Questions in Section A are measured using nominal and ordinal scales. Section B to Section J of the questionnaire comprises 59 questions regarding the independent and dependent variables. Of these, 12 questions examine performance expectancy. Another 12 questions in Section $\mathrm{C}$ which are related to effort expectancy. Section C comprises 12 questions that measure effort expectancy. Seven questions in Section D are used to measure social influence. Four questions in Section $\mathrm{E}$ which are related to facilitating conditions. Nine questions in section $\mathrm{F}$ are related to perceived credibility. Seven questions in section G are used to measure anxiety. Self-efficacy is measured by four questions in section $\mathrm{H}$. Fourquestions in section I are related to attitude towards using Internet banking. In addition, three questions in section $\mathrm{J}$ are used to measure behavioural intention to use Internet banking services. These questions are measured using 5-point Likert's scale, 1 - Strongly Disagree, 2 - Disagree, 3 Neutral/Unsure, 4 - Agree, and 5 - Strongly Agree. After filtering questionnaires with incomplete answers, a total of 666 valid responses, 333 questionnaires from the United States and 333 questionnaires from Malaysia were used for further statistical analyses.

\section{Result}

Table 1 shows that 58.9 percent of the respondents in the United States are females and 93.3 percent of them are young adults in the age range of 20-40. As for Malaysia, the numbers of male (167) and female (166) respondents are almost equal. Most respondents (93.1 percent) are young adults aged 20-40 years old.

Table 1. Respondents' demographic information

\begin{tabular}{|c|c|c|c|c|c|}
\hline & & & United States & Malaysia & Total \\
\hline \multirow{4}{*}{ Gender } & Male & Count & 137 & 167 & 304 \\
\hline & \multirow{3}{*}{ Female } & Percentage & 41.1 percent & 50.2 percent & 45.6 percent \\
\hline & & Count & 196 & 166 & 362 \\
\hline & & Percentage & 58.9 percent & 45.9 percent & 54.4 percent \\
\hline \multirow{4}{*}{ Age Group } & Young & Count & 311 & 310 & 621 \\
\hline & Adults (20-40 years old) & Percentage & 93.3 percent & 93.1 percent & 93.2 percent \\
\hline & Middle-Aged Adults & Count & 22 & 23 & 45 \\
\hline & (41-55 years old) & Percentage & 6.6 percent & 6.9 percent & 6.8 percent \\
\hline
\end{tabular}

As indicated in Table 2, Malaysian females have significantly higher behavioural intention to use Internet banking services compared to their counterparts in the United States(t-statistics $=2.624$, p-value $=0.009$ ). Malaysian females perceive performance expectancy (t-statistics $=2.658$, p-value $=0.008$ ) and facilitating conditions (t-statistics $=2.317$, p-value $=0.021$ ) as more important in determining behavioural intention to use Internet banking services while social influence plays a more important role in affecting Internet banking acceptance of American females(t-statistics $=2.760$, p-value $=0.006$ ). Therefore, H1, H3, H7 and H9 are supported. 
Table 2. Gender effect on internet banking acceptance

\begin{tabular}{|c|c|c|c|c|c|}
\hline Gender & & Nationality & Mean & t-statistics & p-value \\
\hline \multirow{14}{*}{ Male } & \multirow{2}{*}{ Performance Expectancy } & Malaysian & 3.84 & 1.616 & .107 \\
\hline & & American & 3.66 & & \\
\hline & \multirow{2}{*}{ Effort Expectancy } & Malaysian & 3.65 & .115 & .909 \\
\hline & & American & 3.64 & & \\
\hline & \multirow{2}{*}{ Social Influence } & Malaysian & 3.25 & -.921 & .358 \\
\hline & & American & 3.33 & & \\
\hline & \multirow{2}{*}{ Facilitating Conditions } & Malaysian & 3.56 & 1.327 & .124 \\
\hline & & American & 3.44 & & \\
\hline & \multirow{2}{*}{ Perceived Credibility } & Malaysian & 3.29 & -.910 & .364 \\
\hline & & American & 3.38 & & \\
\hline & Attitude towards Using Internet & Malaysian & 3.59 & -.736 & .073 \\
\hline & Banking Services & American & 3.66 & & \\
\hline & \multirow{2}{*}{$\begin{array}{l}\text { Behavioural Intention to Use Internet } \\
\text { Banking Services }\end{array}$} & Malaysian & 3.81 & 1.074 & .284 \\
\hline & & American & 3.70 & & \\
\hline \multirow{14}{*}{ Female } & \multirow{2}{*}{ Performance Expectancy } & Malaysian & 3.83 & 2.658 & $.008 * * *$ \\
\hline & & American & 3.59 & & \\
\hline & \multirow{2}{*}{ Effort Expectancy } & Malaysian & 3.62 & .777 & .437 \\
\hline & & American & 3.56 & & \\
\hline & \multirow{2}{*}{ Social Influence } & Malaysian & 3.11 & 2.760 & $.006 * * *$ \\
\hline & & American & 3.33 & & \\
\hline & \multirow{2}{*}{ Facilitating Conditions } & Malaysian & 3.54 & 2.317 & $.021 * *$ \\
\hline & & American & 3.35 & & \\
\hline & \multirow{2}{*}{ Perceived Credibility } & Malaysian & 3.22 & -1.106 & .269 \\
\hline & & American & 3.31 & & \\
\hline & Attitude towards Using Internet & Malaysian & 3.60 & -.118 & .906 \\
\hline & Banking Services & American & 3.61 & & \\
\hline & Behavioural Intention to Use Internet & Malaysian & 3.79 & 2.624 & $.009 * * *$ \\
\hline & Banking Services & American & 3.56 & & \\
\hline
\end{tabular}

** Significant at 0.05 level; ***Significant at 0.001 level.

As depicted in Table 3, young adults in the United States have more positive attitude towards using Internet banking services compared to young adults in Malaysia ( $\mathrm{t}$-statistics $=-2.473$, $\mathrm{p}$-value $=0.014$ ). Young adults in the United States are more likely to be influenced by their social environment when using Internet banking services compared to young adults in Malaysia ( $\mathrm{t}$-statistics $=-2.927$, $\mathrm{p}$-value $=0.004)$.

On the other hand, middle-aged adults from Malaysia have significantly higher behavioural intention to use Internet banking services compared to Americans ( $\mathrm{t}$-statistics $=3.834$, $\mathrm{p}$-value $=0.000$ ). They perceive performance expectancy ( $\mathrm{t}$-statistics $=4.474$, $\mathrm{p}$-value $=0.000)$, effort expectancy (t-statistics $=3.365$, $\mathrm{p}$-value $=$ 0.002 ), facilitating conditions ( $\mathrm{t}$-statistics $=2.451, \mathrm{p}$-value $=0.017$ ) and attitude towards using Internet banking (t-statistics $=2.622, \mathrm{p}$-value $=0.012)$ as more important in affecting behavioural intention to use internet banking services compared to their counterparts in the United States. Therefore, H2, H4, H8, H10 are supported. 
Table 3. Age effect on internet banking acceptance

\begin{tabular}{|c|c|c|c|c|c|}
\hline Age & & Nationality & Mean & t-statistics & p-value \\
\hline \multirow{15}{*}{$\begin{array}{l}\text { Young Adults } \\
\text { (20-40 years old) }\end{array}$} & \multirow{2}{*}{ Performance Expectancy } & Malaysian & 3.81 & .690 & .490 \\
\hline & & American & 3.76 & & \\
\hline & \multirow{2}{*}{ Effort Expectancy } & Malaysian & 3.62 & -.942 & .347 \\
\hline & & American & 3.68 & & \\
\hline & \multirow{2}{*}{ Social Influence } & Malaysian & 3.18 & -2.927 & $.004 * * *$ \\
\hline & & American & 3.35 & & \\
\hline & \multirow{2}{*}{ Facilitating Conditions } & Malaysian & 3.56 & 1.134 & .257 \\
\hline & & American & 3.48 & & \\
\hline & \multirow{2}{*}{ Perceived Credibility } & Malaysian & 3.25 & -2.338 & $.020 * *$ \\
\hline & & American & 3.40 & & \\
\hline & Attitude towards Using Internet & Malaysian & 3.59 & -2.473 & $.014 * *$ \\
\hline & Banking Services & American & 3.75 & & \\
\hline & Behavioural Intention to Use Internet & Malaysian & 3.80 & .705 & .481 \\
\hline & \multirow[t]{2}{*}{ Banking Services } & American & 3.74 & & \\
\hline & & Malaysian & 4.13 & 4.474 & $.000 * * *$ \\
\hline \multirow{13}{*}{$\begin{array}{c}\text { Middle-Aged } \\
\text { Adults (41-55 } \\
\text { years old) }\end{array}$} & Performance Expectancy & American & 3.24 & & \\
\hline & \multirow{2}{*}{ Effort Expectancy } & Malaysian & 3.78 & 3.365 & $.002 * * *$ \\
\hline & & American & 3.32 & & \\
\hline & \multirow{2}{*}{ Social Influence } & Malaysian & 3.25 & -.053 & .958 \\
\hline & & American & 3.26 & & \\
\hline & \multirow{2}{*}{ Facilitating Conditions } & Malaysian & 3.48 & 2.451 & $.017 * *$ \\
\hline & & American & 3.11 & & \\
\hline & \multirow{2}{*}{ Perceived Credibility } & Malaysian & 3.34 & 1.280 & .208 \\
\hline & & American & 3.14 & & \\
\hline & Attitude towards Using Internet & Malaysian & 3.74 & 2.622 & $.012 * *$ \\
\hline & Banking Services & American & 3.31 & & \\
\hline & Behavioural Intention to Use Internet & Malaysian & 3.89 & 3.834 & $.000 * * *$ \\
\hline & Banking Services & American & 3.25 & & \\
\hline
\end{tabular}

**Significant at 0.05 level; ***Significant at 0.001 level.

\section{Discussion and Recommendation}

\subsection{Gender Effect on Internet Banking Acceptance}

Malaysian females have significantly higher behavioural intention to use Internet banking services compared to their counterparts in the United States. As a member of a particularistic culture which emphasize more on friendships and close relationships (Trompenaars \& Hampden-Turner, 1998), Malaysian females probably are more eager in using the Internet to complete their banking tasks efficiently so that they have more time for their friends and families.

Malaysian females also perceive performance expectancy as a more important factor affecting Internet banking adoption compared to females in the United States. The result strengthens the findings of Hamid et al. (2007) which found that customers in the developing country gradually shift from traditional banking to Internet banking services to increase performance expectancy. Transaction cost reduction is the main benefit of Internet banking in the developing country. Malaysian females tend to hope that their current Internet banking services can be more efficient and effective in eliminating geographical distance between consumers and bankers.

In addition, Malaysian females also perceive facilitating conditions as more important in determining Internet banking acceptance compared to American females. As a member of a high power distance country, Malaysian females seem to be highly relied on resources such as specialist, hardware, software, and process documentation to facilitate their Internet banking experience (Hofstede, 2001).

Therefore, web developers should concentrate on providing comprehensive, accurate and relevant information on banks' websites in order to attract more Malaysian females to use Internet banking. Concise and uncomplicated wordings should be used to make sure the descriptions relating to the benefits of Internet banking services are easily understandable while still covering all the banking product's key features. Web designers 
should not only emphasize Internet banking benefits by providing robust banking product/services content in the form of a detailed product overview and product specifications, but should continue to support the Internet banking transactions with interactive user guides and demonstrations.

In contrast, social influence plays a more important role in affecting Internet banking acceptance of American females compared to Malaysians. One possible explanation might be because as members of a Mastery culture, females in the United States tend to give higher priority on group success and competence (Schwartz, 1994). In order to enhance Internet banking acceptance, a knowledge sharing session shall be conducted for an American female Internet banking users to alert other people in his/her organization about the opportunity of forming strategic partnership with an Internet bank to allow customers to search and place an order of their company products while surfing the Internet banking websites.

Males in the United States and Malaysia exhibit no significant difference in behavioural intention to use Internet banking services, performance expectancy, effort expectancy, social influence, facilitating conditions, perceived credibility and attitude towards using Internet banking services of male respondents from the United States and Malaysia. The finding of this study strengthen Khan and Mahapatra (2009) and Somali et al. (2008)'s results that there is no significant influence on the Internet banking acceptance of males from the developed countries such as New Zealand and developing countries such as India. One possible explanation is that males from the United State and Malaysia who are busy with their work are equally impressed with the convenience of 24/7 access and also the ability to use Internet banking whenever there is a spare moment. In order to improve Internet banking acceptance of male respondents in the United States and Malaysia, marketing practitioners should conduct a seminar jointly with the participating online brokerage firms to create awareness about the convenience and efficiency of online stock investments at Internet banking websites.

\subsection{Age Effect on Internet Banking Acceptance}

Young adults in the United States have more positive attitude towards using Internet banking services compared to young adults in Malaysia. United States is alow uncertainty avoidance country where creative and innovative ideas from young adults are most welcomed (Hofstede, 2001). In low uncertainty avoidance culture, American young adults are more curious and encouraged to learn and explore more on how to complete banking transaction online. Thus, they are more interested in learning how to use Internet banking services compared to their counterparts in Malaysia (Hofstede, 2001).

Besides traditional advertising media such as newspaper, television and radio, web advertisements such as Internet banner advertisements, e-mail advertisements, online press release advertisements and search engine advertisements can also be used to create awareness and promote interest in using Internet banking services among young adults in Malaysia. Web advertisements are cheaper than advertisements in traditional media. Another key advantage of web advertisement is that it offers richer content such as text, graphics and animation, which can be effectively combined to draw interest of young adults.

Young adults in the United States are more likely to be influenced by their social environment when using Internet banking services compared to young adults in Malaysia. As members of a short-term oriented culture, young adults in the United States tend to focus more on traditions and fulfilling social obligations (Hofstede, 2001). Given this perspective, young adults in the United States are more easily influenced by their friends and colleagues in using Internet banking services for quick results within the work place (Hofstede, 2001).Web developers could therefore try to develop interesting online financial games that require young adults to work closely with their friends and colleagues to develop a mix of entertainment and basic Internet banking skills to become the winner of the game. The main objective of providing this online financial game on the Internet banking web site is to instil interest among young adults in the United States. Web developers should assure that there is no actual financial loss in this game in order to encourage young users' participation.

On the other hand, middle-aged adults from Malaysia rank significantly higher on behavioural intention to use Internet banking services, performance expectancy, effort expectancy, facilitating conditions and attitude towards using Internet banking compared to their counterparts in the United States. Interactions between middle-aged people in a diffuse culture such as Malaysia are enchanted by virtues such as trust and mutual understanding. Middle-aged adults in Malaysia emphasize more on family, friends and future compared to their counterparts form the United States (Trompenaars \& Hampden-Turner, 1998). They probably wish to use Internet banking to expedite their banking tasks so that they have ample time to participate in daily activities such as tennis and cooking with their friends and families (Trompenaars \& Hampden-Turner, 1998). Free education should be provided to those above 40 years old in the Malaysia so that they can have a wonderful 
personal experience of trying various convenient and easy to access transactional and communicative Internet banking services offered by the financial institutions nowadays.

\section{Limitation of Study}

The results of this study are applicable only to Internet banking customers in the United States and Malaysia as the data are collected from these countries. Future research could apply the research framework of this study in other developed and developing countries by using the same cultural factors. Future research could also be carried out to examine the moderating effect of education and family background on Internet banking acceptance so that bank industry can provide customized Internet banking services to users from different backgrounds.

\section{Acknowledgements}

The author would like to sincerely thank Associate Professor Dr. Paul Heng Ping Yeow, Dr. Nena Lim and Dr. Najib Saylani for their supports and guidance throughout this research.

\section{References}

AbuShanab, E., \& Pearson, J. M. (2007). Internet banking in Jordan: The unified theory of acceptance and use of technology (UTAUT) perspective. Journal of Systems and Information Technology, 9(1), 78-97. http://dx.doi.org/10.1108/13287260710817700

Ajzen, I., \& Driver, B. L. (1992). Application of the theory of planned behaviour to leisure choice. Journal of Leisure Research, 24(3), 207-224.

Alagheband, P. (2006). Adoption of e-banking services by Iranian customers. Unpublished Master Thesis. Lulea University of Technology.

Ali, A. S., \& Khalil, M. N. (2013). Influencing factors on behavioural intention to adopt internet banking service. World Applied Sciences Journal, 22(11), 1652-1656. http://dx.doi.org/10.5829/idosi.wasj.2013.22.11.2896

Angie, N. K., \& Chow, W. S. (2006). A study of trust in e-shopping before and after first-hand experience is gained. Journal of Computer Information Systems, 46(4), 125-130.

Bhattacherjee, A. (2001). Understanding information systems continuance: An expectation-confirmation model. MIS Quarterly, 25(3), 351-363. http://dx.doi.org/10.2307/3250921

Calisir, F., \& Gumussoy, C. A. (2008). Internet banking versus other banking channels: Young consumers' view. International Journal of Information Management, 28(3), 215-221. http://dx.doi.org/10.1016/j.ijinfomgt.2008.02.009

Capgemini, European Financial Management and Marketing Association. (2009). World retail banking report. Retrieved from http://www.capgemini.com/resources/world_retail_banking_report_2009pdf

Capgemini, European Financial Management and Marketing Association. (2013). World retail banking report. Retrieved from http://www.capgemini.com/sites/default/files/resource/pdf/wrbr_2013_0.pdf

Chen, Y. H., \& Barnes, S. (2007). Initial trust and online buyer behaviour. Industrial Management Data System, 107(1), 21-36. http://dx.doi.org/10.1108/02635570710719034

Davis, F. D. (1989). Perceived usefulness, perceived ease of use and user acceptance of information technology. MIS Quarterly, 13(3), 319-340. http://dx.doi.org/10.2307/249008

Eriksson, K., Kerem, K., \& Nilsson, D. (2005). Customer acceptance of Internet banking in Estonia. International Journal of Bank Marketing, 23(2), 200-216. http://dx.doi.org/10.1108/02652320510584412

Evans, P. B., \& Wurster, T. S. (1997). Strategy and the new economics of information. Harvard Business Review, September-October, 71-82.

Floh, A., \& Treiblmaier, H. (2006). What keeps the e-banking customer loyal? A multi-group analysis of the moderating role of consumer characteristics on e-loyalty in the financial services industry. Journal of Electronic Commerce Research, 7(2), 97-110.

Gerrard, P., \& Cunningham, J. B. (2003). The diffusion of Internet banking among Singapore consumers. The International Journal of Bank Marketing, 2l(1), 16-28. http://dx.doi.org/10.1108/02652320310457776

Gounaris, S., \& Koritos, C. (2008). Investigating the drivers of Internet banking adoption decision: A comparison of three alternative frameworks. International of Bank Marketing, 26(5), 282-304. http://dx.doi.org/10.1108/02652320810894370 
Hamid, M. R., Amin, H., Lada, S., \& Ahmad, N. (2007). A comparative analysis of Internet banking in Malaysia and Thailand. Journal of Internet Business, 4(1), 1-19.

Hofstede, G. (2001). Culture's consequences: Comparing values, behaviours, institutions, and organizations across nations. Thousand Oaks, CA: SAGE Publications.

Homburg, C., \& Giering, A. (2001). Personal characteristics as moderators of the relationship between customer satisfaction and loyalty. Psychology and Marketing, 18(1), 43-66. http://dx.doi.org/10.1002/1520-6793(200101)18:1<43::AID-MAR3>3.0.CO;2-I

Hsu, M. H., Yen, C. H., Chiu, C. M., \& Chang, C. M. (2006). A longitudinal investigation of continued online shopping behaviour: An extension of the theory of planned behaviour. International Journal of Human-Computer Studies, 64(9), 889-904. http://dx.doi.org/10.1016/j.ijhcs.2006.04.004

Hussain, O. H., Chang, E., Hussain, F. K., \& Dillon, T. S. (2009). Determiningthe failure level for risk analysis in an e-commerce interaction. Springer, Berlin: Heidelberg.

Internet World Stats. (2013). Internet usage stats and telecommunications market report. Retrieved from $\mathrm{http}: / / \mathrm{www}$. Internetworldstats.com/pacific.htm

Karjaluoto, H., Jarvenpaa, L., \& Kauppi, V. (2009). Antecedents of online banking satisfaction and loyalty: Empirical evidence from Finland. International Journal of Electronic Finance, 3(3), 253-269. http://dx.doi.org/10.1504/IJEF.2009.027849

Khan, M. S., \& Mahapatra, S. S. (2009). Service quality evaluation in Internet banking: An empirical study in India. International Journal of Indian Culture and Business Management, 2(1), 30-46. http://dx.doi.org/10.1504/IJICBM.2009.021596

Kumar, S. (2013). The moderating factors of $3 \mathrm{G}$ user acceptance technology in Shimla (India) using UTAUT model. International Journal of Computer Science \& Engineering Technology, 4(6), 670-674.

Lichtenstein, S., \& Williamson, K. (2006). Understanding consumer adoption of Internet banking: An interpretive study in the Australian banking context. Journal of Electronic Commerce Research, 7(2), $50-66$.

Maenpaa, K. (2006). Clustering the consumers on the basis of their perceptions of the Internet banking services. Internet Research, 16(3), 304-322. http://dx.doi.org/10.1108/10662240610673718

Morahan-Martin, J. (2000). Women and the Internet: Promise and perils. Cyber Psychology Behaviour, 3(5), 683-691. http://dx.doi.org/10.1089/10949310050191683

Mukherjee, A., \& Nath, P. (2003). A model of trust in online relationship banking. International Journal of Banking Marketing, 21(1), 5-15. http://dx.doi.org/10.1108/02652320310457767

Polatoglu, V. N., \& Ekin, S. (2001). An empirical investigation of the Turkish consumers' acceptance of Internet banking services. International Journal of Bank Marketing, 19(4), 156-165. http://dx.doi.org/10.1108/02652320110392527

Raman, A., \& Don, Y. (2013). Preservice Teachers' Acceptance of Learning Management Software: An Application of the UTAUT2 Model. International Education Studies, 6(7), 157-164. http://dx.doi.org/10.5539/ies.v6n7p157

Roca, J. C., Chiu, C. M., \& Martinez, F. J. (2006). Understanding e-learning continuance intention: An extension of the technology acceptance model. International Journal of Human-Computer Studies, 64(8), 683-696. http://dx.doi.org/10.1016/j.ijhcs.2006.01.003

Rotchanakitumnuai, S., \& Speece, M. (2003). Barriers to Internet banking adoption: A qualitative study among corporate customers in Thailand. International Journal of Bank Marketing, 21(6/7), 312-323. http://dx.doi.org/10.1108/02652320310498465

Sathye, M. (1997). Internet banking in Australia. Journal of Internet Banking and Commerce, 2(4), September.

Schwartz, S. H. (1994). Beyond individualism and collectivism: New cultural dimensions of values. In Kim, U., Triandis, H. C., Kagitcibasi, C., Choi, S. C., and Yoon, G. (Eds.), Individualism and collectivism: Theory, method, and applications (pp. 85-122). Newbury Park, CA: Sage Press.

Sciglimpaglia, D., \& Ely, D. (2002). Internet banking: A customer-centric perspective, System Sciences, HICSS. Paper presented at the Proceedings of the 35th Annual Hawaii International Conference, 2420-2429. 
Shumaila, Y., Pallister. J., \& Foxall, G. (2009). Multi-dimensional role of trust in Internet banking adoption. The Service Industries Journal, 29(5), 591-605. http://dx.doi.org/10.1080/02642060902719958

Somali, S. A., Gholami, R., \& Clegg, B. (2008). An investigation into the acceptance of online banking in Saudi Arabia. Technovation, 29(2), 130-141. http://dx.doi.org/10.1016/j.technovation.2008.07.004

Sullivan, R. J. (2000). How has the adoption of Internet banking affected performance and risk in banks? Financial industry perspectives. Federal Reserve Bank of Kansas City, December, 1-16.

Taylor, S., \& Todd, P. A. (1995). Understanding information technology usage: A test ofcompeting models. Information Systems Research, 6(2), 144-176. http://dx.doi.org/10.1287/isre.6.2.144

Thompson, R. L., Higgins, C. A., \& Howell, J. M. (1994). Influence of experience on personal computer utilisation: Testing aconceptual model. Journal of Management Information Systems, 11(Summer), $167-187$.

Trompenaars, F., \& Hampden-Turner, C. (1998). Riding the waves of culture (1st ed.). New York: MacGraw-Hill.

Vainio, H. M. (2006). Factors influencing corporate customers' acceptance of Internet banking: Case of Scandinavian trade finance customers. Unpublished M.Sc. Thesis in Accounting. The Swedish School of Economics and Business Administration.

Venkatesh, V., Morris, M. G., Davis, G. B., \& Davis, F. D. (2003). User acceptance of information technology: toward a Unified View. MIS Quarterly, 27(3), 425-478.

Yang, Y. (2009). Research procedures: Economic research methods lecture notes (1st ed.). California State University: Sacramento Department of Economics.

Yazan, K. A. M. (2008). Quantitative evaluation of the Internet banking services encounter's quality: comparative study between Jordan and the UK retail banks. Journal of Internet Banking and Commerce, $13(2)$.

Zolait, A. H. S., Mattila, M., \& Ainin, S. (2009). The effect of user's informational-based readiness on innovation acceptance. International Journal of Bank Marketing, 27(1), 76-100. http://dx.doi.org/10.1108/02652320910928236

\section{Copyrights}

Copyright for this article is retained by the author(s), with first publication rights granted to the journal.

This is an open-access article distributed under the terms and conditions of the Creative Commons Attribution license (http://creativecommons.org/licenses/by/3.0/). 